\title{
ANÁLISIS
}

\section{INTEGRATED COMMUNICATION 2.0 IN MUNICIPAL ADMINISTRATION}

\author{
Comunicación integrada 2.0 en la \\ administración municipal
}

Concepción Campillo-Alhama and Alba-María Martínez-Sala

Nota: Este artículo se puede leer en español en:

https://recyt.fecyt.es/index.php/EPI/article/view/58738

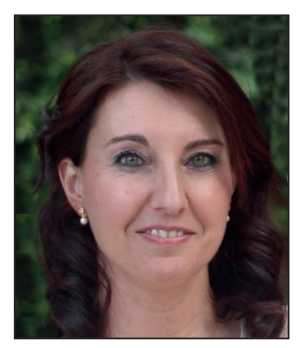

Concepción Campillo-Alhama, graduated in Communication from the Universidad Complutense de Madrid (advertising and public relations) and PhD in Sociology from the University of Alicante (UA), is an associate professor in the Department of Communication and Social Psychology at the UA. In 2010 she got the Blas Infante award (Study and research on public administration and management), awarded by the Andalusian Institute of Public Administration (IAAP). Her research focus on the administrative and proximity communication of municipal organizations, the advertising strategy and the management of institutional relations. She is a member of the research groups Compubes (Communication and specific audiences) and Gepips (Institutional, political and social advertising) of the UA.

http://orcid.org/0000-0001-9886-0049

concepcion.campillo@ua.es

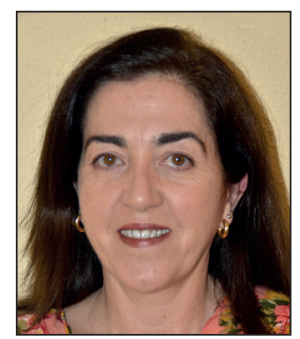

Alba-María Martínez-Sala is an associate professor in the Department of Communication and Social Psychology at the University of Alicante and a lecturer in the Official Master's Degree in Organization of Events, Protocol, and Institutional Relations of IMEP-UMH. She graduated in advertising from the Universidad Complutense de Madrid and got a PhD from the University Miguel Hernández. Her research focuses on digital communication strategies in the public and private spheres, analyzing the impact of 2.0 models and social media. She is a member of the research group Compubes (Communication and specific audiences) of the UA.

http://orcid.org/0000-0002-6852-6258

albamaria.martinez@ua.es

University of Alicante, Department of Communication and Social Psychology, School of Economic and Business Sciences Campus San Vicente del Raspeig, Ap. 99. 03080 Alicante, Spain

\begin{abstract}
Municipal communication transcends the simple information about public services, activities, projects, and administrative procedures. Communicative and information strategies in the local context are oriented towards citizens who participate in a shared municipal project in which they are prosumers in the design and development of sectorial strategies linked to public policies. Consequently, city councils must integrate a communication structure that takes advantage of public information from governance, transparency, and proactive citizen participation. Since the first Spanish democratic legislature in 1979 the evolution and adaptation of process and production routines has been justified by the need to shape a positive perception of government action and consolidate their institutional reputation. In this paper an approach to municipal communication, based on the rigid and standardized models of the $80 \mathrm{~s}$ and $90 \mathrm{~s}$, is presented to influence the current revolution that represents the paradigm of communication 2.0, the implementation of the social web in the context of proximity and social media strategy.
\end{abstract}

\section{Keywords}

Public information; Town hall; City councils; Communication management; Web 2.0; Social media; Social networks.

\section{Resumen}

La comunicación municipal trasciende la simple información sobre servicios públicos, actividades, proyectos o trámites administrativos. Las estrategias comunicativas y de información en el contexto local se orientan hacia los ciudadanos para 
poner en valor un proyecto municipal compartido en el que éstos se implican como prosumidores en el diseño y desarrollo de estrategias sectoriales vinculadas a las políticas públicas. En consecuencia, los ayuntamientos deben integrar en su estructura una dirección de comunicación que asuma la función de información pública desde la gobernanza, la transparencia y la participación ciudadana proactiva. Desde la primera legislatura democrática en 1979 la evolución y adaptación de sus procesos y rutinas productivas se justifica por la necesidad de configurar una percepción positiva de la acción del gobierno y consolidar su reputación institucional. En este trabajo se realiza una aproximación a la dirección de comunicación municipal basada en los modelos rígidos y estandarizados de los años 80 y 90, para incidir en la revolución actual que representa el paradigma de la comunicación 2.0, la implementación de la web social en el contexto de proximidad y la estrategia de medios sociales.

\section{Palabras clave}

Información pública; Ayuntamientos; Dirección de comunicación; Web 2.0; Medios sociales; Redes sociales.

Campillo-Alhama, Concepción; Martínez-Sala, Alba-María (2017). "Integrated communication 2.0 in municipal administration". El profesional de la información, v. 26, n. 3, pp. 507-515.

https://doi.org/10.3145/epi.2017.may.17

\section{Introduction}

Since the first Spanish democratic legislature (1979-1983), councils, which are corporations under public law, have experienced a dramatic transformation in power and implementation of strategic municipal policies. This circumstance has led to local bureaucratic models similar to those in the 1980s and 1990s, which assumed administrative management based on a one-way communication model, and eventually evolved into the current management models, which are much more relational, participatory, bi-directional, and multi-directional (Ramió-Matas, 1999; Olías-de-Lima, 2001; Gómez-Roa, 2013; Criado-Grande; Rojas-Martín, 2013; Jiménez-Asensio, 2014).

During the second (1983-1987) and third (1987-1991) legislatures, and as a result of the democratization process, municipal organizations implemented communication structures to develop communication of proximity in their interactions with citizens.

Since the late 1990 s we have been in a context characterized by transparency and active collaboration and participation by citizens in local policies

In turn, this led to the emergence of information management units, in the form of institutional communication cabinets and press offices, which developed external communication functions. Initially, they were strictly created for the establishment and management of information relations with the media. These functions were expanded, as Ramírez-de-la-Piscina (1995) points out, to the design and execution of advertising campaigns and the management of institutional relations' initiatives to strengthen organizational links with the social system.

Such communication structures convey a message related to political and administrative management based on the fundamental premise that the citizen, as the epicenter of the actions of the local government, should be informed of all the actions and initiatives that have an impact on their condition (Campillo-Alhama, 2010, 2011).

However, since the late 1990s we have been in a context characterized by transparency and active collaboration and participation by citizens in local policies, where municipal communication goes beyond the mere dissemination of information about public services, activities, projects, and administrative procedures. Communication and information strategies have begun to focus on citizens sharing in municipal projects, in ways in which citizens get proactively involved in the design and development of different sectoral strategies linked to the achievement of public policy goals.

This evolution of organizational culture, based on the concept of open government (Gómez-Roa, 2013), together with the emergence of new technologies (communication 2.0, social networks, and digital media and platforms) has had a very direct impact on the restructuring of the administrative units that plan information strategies. They must now explain, justify, and legitimize the political decisions of the municipal government.

This article describes the main features of the strategic, functional, and operational communication models implemented by local councils as political-administrative organizations during the 1980s and 1990s, to discuss, in the context of the digital society, the evolution of municipal communication management as a complex structure that integrates new roles and professional profiles linked to the functions of communication 2.0 and relational management. These are new features that respond to the current challenges of the municipal administration in relation to groups that are conveniently segmented by socio-demographic or psychographic criteria.

After a review of professional roles that specialize in digital communication, we propose a strategic model for integrated municipal communication -traditional and online-, based on two key references: the strategic territorial plan and the agenda of the local powers. The orientation of this model is based on governance, transparency, and representative citizen participation as a booster of sectoral public policies. 


\section{Evolution of public communication and information structures in municipal councils: Professional roles and functions}

The socio-demographic, economic, cultural, and political characteristics of the Spanish municipalities vary widely and, therefore, each municipal council must establish a system of information management that will condition the centralized or decentralized- organizational structure of the communication management office, its processes, routines, and (technical, human, and financial) resources. Other conditions of this structure are the characteristics of the local media:

- online or traditional; private or municipal;

- centralized or decentralized organization chart of the municipality;

- organic or territorial level;

- taxonomic map of the stakeholders linked to the entity;

- engagement established with them; and

- relations that need to be introduced and strengthened.

Municipal communication offices are organized and stable sources of information that have a defined structure to develop public communication functions. It is the reference unit of the highest political and administrative authorities in the various municipal management areas and departments, when authorities want to share public information about actions, initiatives, and projects with citizens, through traditional, online, and social media.

We propose a strategic model for integrated municipal communication -traditional and online-, based on two key references: the strategic territorial plan and the agenda of the local powers

Despite the fact that relations with the media have traditionally been a fundamental function assumed by the municipal communications' offices (Díez-Lobo, 2004; Almansa-Martínez, 2005; Campillo-Alhama, 2013), this function, anchored in the early years of the establishment of the democratic municipal councils, cannot be developed in the current context of the digital society without the backing of other communication activities linked to the philosophy of web 2.0. Thus, the communication offices in the municipalities have been expanded into a complex structure with new features and professional roles, with deep dependencies and synergies between its vertical and horizontal hierarchy.

As Freixa-Matallonga (2004) and Campillo-Alhama (2010, 2011) have pointed out, since the beginning of the new miIlennium public organizations have integrated the management, documentation, and monitoring of political and administrative information in the media (Bustelo-Ruesta, 2011) with the traditional functions of information relations, the processes of institutional communication and advertising, and the institutional relations of the 1980s and 1990s. For this reason, the use of purpose-created computer applica- tions and the use of new technologies in information documentation have become an outstanding added value for the management of the processes and routines of the communication offices (Campillo-Alhama, 2013).

This extension of the instrumental and strategic professional roles of the 1980s and 1990s (Timoteo-Álvarez, 2013), with the activity linked to the documentation and monitoring of public information, became the first major transformation of the executive functions in municipal communication.

In the last decade, a second turning point occurred when new functions linked to communication 2.0, social media, and social networking sites emerged in public administration (Graells-Costa, 2012; Ballester-Espinosa, 2013; CriadoGrande; Rojas-Martín, 2013; Palomar-Baget, 2015; Diputación de Alicante, 2015), which is especially noticeable at the municipal level as a context of proximity.

\section{Structural and functional models of municipal communication}

As we have already noted, during the 1980s, communication management offices had purely instrumental character without recurring models in public organizations (PérezGonzález, 1988). Communication management became strategic in the 1990s with structural and functional communication models (Puig-Picart, 2003; Freixa-Matallonga, 2004; Rubio-Oderiz, 2005; Campillo-Alhama, 2010) and evolved, this past decade, towards the current digital context. Municipal councils, as entities that act as permanent information generators, are not alien to such a transformation in the structures, functions, and roles linked to communication management.

During the 1980s, Pérez-González (1988) proposed a strategic communication model based on six phases:

- research of public opinion related to municipal administration through surveys;

- analysis of information published in the media in different areas of political and administrative management;

- management balance by municipal administration;

- communication strategy of the balance of municipal administration;

- corporate identity program, urban signage; and

- implementation of the communication strategy with its monitoring and adaptation.

The structural and functional models of the 1990s and early $21^{\text {st }}$ century, proposed by authors such as Ramírezde-la-Piscina (1995), Álvarez-Domínguez; Caballero-Hueso (1997), Freixa-Matallonga (2004) and Campillo-Alhama (2010), have significant similarities in four global areas of intervention based on the management of information relations, marketing and advertising, relations with society, and internal relations with derived communication processes. Freixa-Matallonga (2004) refers in this regard to the most significant functions of municipal communication management, and associates them with:

- internal and external communication;

- institutional advertising;

- spokesmanship;

- management of corporate branding and image; 
- crisis communication;

- corporate culture;

- social policy communication;

- generation of publications and audio-visual material;

- sponsorship and patronage;

- advice to the government team and its highest political representative;

- public and institutional relations;

- organization of events;

- event management and protocol;

- relations with lobbyists;

- relations with the media; and

- e-communication.

Unlike the previous models, the municipal communication model of Puig-Picart (2003) does not present a sequential proposal, but instead identifies city branding as the epicenter of the performance of local councils. It is a radial system that highlights the variables of public communication management. The brand constitutes the main reference when it comes to developing organizational communication -both internal and external- through:

- corporate image;

- conventional and non-conventional communication;

- press office;

- catalog of services;

- relations with organizations;

- electronic communication;

- information and service centers;

- systems of complaints and suggestions;

- personalization of services; and

- own media.

For his part, Rubio-Oderiz (2005) identifies three concentric areas in the process of public communication of councils: operation, leadership, and socialization and identification. Operation is linked to the provision of public services by the municipal entity, facilitating knowledge and accessibility; it is based on the information of the rights and obligations of citizens, as well as the functioning and operations of municipal services. The activities carried out in the area of leadership are associated with the objectives of motivation of stakeholders, innovation, social change, and the maintenance of social networks among individuals. This area identifies the public institution as the global system and as a driver of social change.

It is articulated through corporate communication aimed at the consolidation of the global image of the organization, building trust and credibility, the promotion of changes in behavior and social values, the organizational view, which is reflected on the information that is shared with citizens by the ideological project of the government team, and the relational vector, which re-orients municipal organizations to develop their work in partnership with other social, economic, and political agents. Through socialization and identification, municipal organizations stimulate citizens' sense of belonging to a local community and favors the formation of active and responsible citizens. This area is manifested by emotional ties with the community, which facilitates the understanding of the processes of public administration and the acceptance of collective interests.
In the current context of the digital society, the revolution posed in local entities by the change in its corporate culture, communication 2.0, and the implementation of new technologies linked to social media, encourages a reformulation of the communication models of the municipal departments, as well as of the new professional roles that are integrated into them.

Municipal communication structures will require media professionals who are able to perform the conventional functions of institutional communication, public information, and institutional relations as well as the analysis of the information published by online and print media through the design of purpose-created applications and techniques of documental management (Campillo-Alhama, 2013). These functions have been incorporated into other functions linked to digital communication, strategic management of social media and social networks, branded-content management, and online reputation ${ }^{1}$.

\section{Social media and public administration: A model of integrated communication}

In the context of public service, social media ${ }^{2}$ and web 2.0 have become authentic digital communication platforms that empower citizens who generate and share content and information through public and private profiles. They are characterized by the dissemination of information and knowledge resources; they facilitate contact between individuals and interest groups, and enable the publication and exchange of personal ideas, opinions, and experiences and the sharing of this information with other users.

Within social media, social networks represent the greatest exponent of the communicative paradigm 2.0 in the central, regional, and local administration, in public and mixed companies, as well as in autonomous bodies. This is because, as Criado-Grande and Rojas-Martín (2013, p. 17) point out:

"the 2.0 nature of social networks in the public sector involves, first, that citizens are potential active agents in the production of web content and act like prosumers; second, the acceptance of collaborative intelligence as evidence that public innovation is also outside the formal boundaries of the municipal organisation; and finally, it involves an increased disintermediation of activities between organisations and individuals. All of this reflects a new scenario for collaboration, transparency, participation and accountability within the public sphere."

From a strictly administrative point of view, social networks become an instrument of direct participation as they promote bi-directionality and multi-directionality in public institutions, innovation, and interest in relational management. Thus, social networks can improve transparency and participation (Graells-Costa, 2012) as they enable citizens to collaborate in the setting and management of the agenda of the local institution (Rojas-Martín, 2013).

Of the diversity of social networks, over the last decade Facebook and Twitter have recurrently been incorporated in the communicative and relational management of the public sector and have become a social, political, and techno- 
logical phenomenon that has transformed the way the municipal administration assumes the governmental functions (Campillo-Alhama; Ramos-Soler, 2013).

This presence on social networks, as Vañó-Sempere (2015) points out, must pursue clear objectives of bi-directional and multi-directional communication, homogeneously and consistently among all the departments of the institution, to improve the institutional image through information about the public corporation, citizen services, activities and calls, as well as the expansion of the forms of contact and communication with the institution.

To this end, it is imperative to establish a strategy for social media (or a strategic plan for presence in social networks) that ensures the continuity and relevance of this interaction, through the establishment of general and specific objectives, the map of networks of the institution, procedures, technical resources and the formation of human resources. This strategy requires active management, not only as a process of external communication, but also as an internal communication unit that coordinates messages among the different departments and areas. This strategy should be useful in the management and effective resolution of crisis situations and in search engine optimization (SEO) to link the institution with its corporate values, initiatives, projects, and services. As a result, the social media strategist -or social media manager- emerges in the public sector as a new professional role that assumes the responsibilities of social media strategy and monitoring.

As for the strategy of content 2.0, based on the objectives set by political-administrative management, it is necessary to determine the target audience, the themes and the messages, the design of the book of style that sets the tone, approach and periodicity of the messages on social networks, the plan of action and the timetable for content, the dissemination typology and channels, the available resources, the preparation of answers for the frequently asked questions of users, and the measurement of the effectiveness of the actions (Moreno-Molina, 2014).

The monitoring of social networks is based on the measuring of the return on investment (ROI) through key performance indicators (KPI) $(I A B, 2012)$, which are based on objectives and indicate their level of achievement through four variables:

- recognition (which measures the initial value of the institution in a given social medium);

- revaluation (which indicates the increase of this value);

- reaction (which indicates whether our actions are effective and whether the user is reacting to them; and

- recommendation (which represents high engagement of the user who acts as an ambassador of the brand among other users).

Vañó-Sempere (2015) says that in the measurement of the results of social media strategies the goal goes far beyond the mere notoriety and visibility of the institution. The objective is to amplify its information and disseminate it across the web, to obtain recommendations and promote communication with stakeholders and the general public. The author also identifies the parameters that must be moni- tored in social network accounts: audience (followers and posts), interactions (users' reactions to posts: likes, shares, retweets, comments, and reactions), interest (interactions related to the posts), and commitment (interactions depending on the audience). All these data are collected periodically to analyze them and adapt the communication strategy according to the results.

Next to the social media strategist, other professional roles linked to digital communication have emerged in the public sector: content manager, content curator, record manager and community manager (Aerco-Territorio Creativo, 2009; Aerco-PSM, 2012; Guallar; Leiva-Aguilera, 2013; MorenoMolina, 2014; Vañó-Sempere, 2015; Carrillo-Durán, 2016; Salaverría, 2016; Villar-Rodríguez, 2016).

The content manager as content generator is responsible for feeding web 2.0, and the institutional blogs and social networks. For this purpose, they use the institution's own content to advertise services, events, initiatives, activities, and projects, complementing the traditional and official channels of public information; content generated by the media, which serves as an amplifier of institutional information; content generated by other official sources that may be of general or specific interest; and content generated by non-official sources with which the institution has collaborated or participated in any activity, event, or project.

The content curator analyzes and filters the immense volumes of information poured in online media on a specific topic and presents the most significant information to institutional authorities in an organized way to provide value and reinforce the content strategy for social media, based on trustworthy and official sources, which are an obligatory reference in public policies and affairs.

The record manager documents the information posted on online and social media on the different departments or areas of management -both centralized and decentralized-, integrated in the public institution, and passes the information on to those responsible for the communication management, which includes the positive, negative, neutral, or ambivalent assessment generated by the media.

The community manager constantly monitors the web in search of conversations about the public institution and its social environment. It passes this information, in a structured way, on to the political and administrative leaders who assume responsibilities for different areas of management and explains the positioning and the decisions taken in relation to citizens. The community manager also actively responds and talks in all social media in which the institution is present and significantly mentioned. It manages the blog of the institution, employing all the multimedia possibilities at has or her fingertips, and also selects and shares content with the stakeholders of the local administration, which have been conveniently segmented, based on the generation and curating of content. They locate opinion leaders and influencers -both internal and external- who can help in the pursuit of the interests of the institution and create forms of collaboration with the local community following the strategy set out in the social media plan. 
All these professional functions and roles linked to new technologies and communication 2.0 have not only affected the restructuring and adaptation of municipal communication management, but also the communicative models that are implemented to translate public policies of proximity to the language of the citizenry.

Based on the previous review, we propose a model of integrated communication (see Figure 1), derived from the strategic territorial plan and the local agenda, guided by an administrative approach based on governance, transparency and the participation of citizen-prosumers, together with different social groups, in the management of public policies.

In the proposed model, the informant entities (centralized, decentralized, and external) and the informant individuals (internal and external to the local administration) participate actively in the design and development of the municipal strategic lines which are identified as sectoral public policies. Through the issues, the territorial strategic lines materialize and gain visibility in the public sphere through the media. In this sense, the model shows a two-way and multi-directional flow in the online strategy, while in the traditional strategy the communication process, which is developed by the informant entities and individuals, is basically one-way. However, this symbiosis between both strategies allows the former to substantially strengthen the effectiveness of the latter. Thus, municipal institutions implement communication 2.0 actions that aim to strengthen relations with the traditional media, to advertise official events and acts, make institutional communication and advertising campaigns go viral, and manage more efficiently the institutional relations through permanent interaction with citizens, which is enabled by social media, the public service municipal offices, and the technological and professionalized processes of citizen participation at the organic, functional, and cooperative levels.

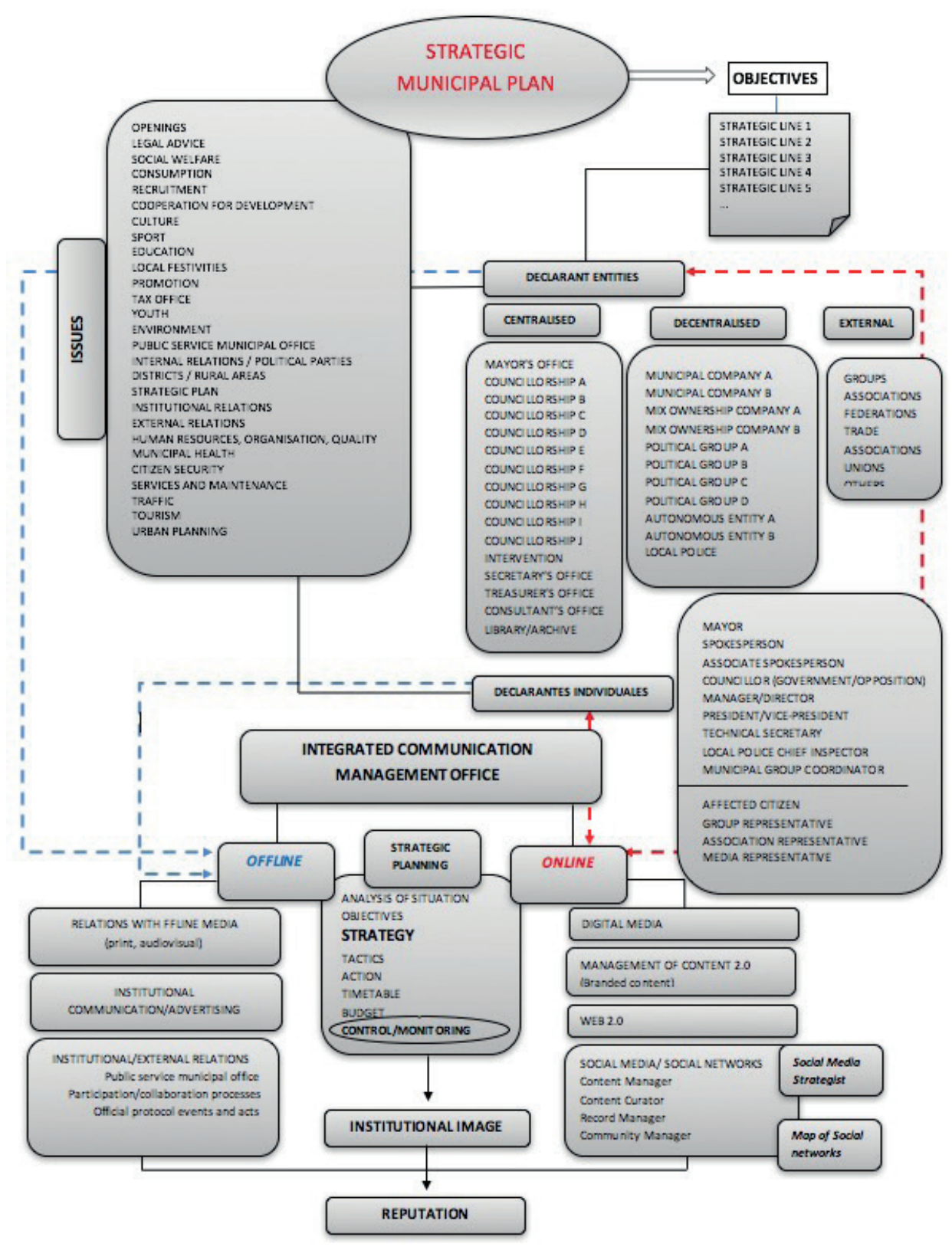

Figure 1. Model of integrated communication derived from the strategic territorial plan and the local agenda 
Municipal communication management based on paradigm 2.0 is a structure that integrates the traditional functions of communication and relational management (relations with the media, institutional communication and advertising, and institutional and external relations), and the new features related to digital communication. All these functions and professional roles are developed by following a general strategic plan, based on a sequential process that ends with the control and monitoring of different tactics and actions when the local institution implements the strategies. This evaluation phase is essential to verifying the effectiveness of such a process, to question it, and adapt it.

The strategic plan represents the permanent axis of reference for integrated communication management. Its coherence with the general objectives will condition the institutional image of the municipal entity, and by extension its administrative reputation, in the mid and long term.

\section{Conclusions}

Municipal institutions as political and administrative organizations must realize the need to adapt their structures of communication and public information to the current context of the digital society. Several studies and analyses have shown that in the last decade many municipalities have progressively and heterogeneously implemented paradigm 2.0, both in their interaction with citizens and in the online communication and information processes, which turns citizens into authentic prosumers of projects, initiatives, and services offered by the local administration.

There are constraints, in this sense, given the socio-demographic characteristics of each municipality, the political stability of the municipal government, the size, structure, economic, human resources, and technological development of the municipal organization, the access of employees to specific training, the experience in the use of social networks and social media, as well as the political and administrative leadership in the involvement and dedication of the people who manage these networks and media.

In the current context of the digital society, the people responsible for political and administrative processes continuously target citizens through messages disseminated across media to advertise actions linked to sectoral public policies. The monitoring of the treatment and contextualization of the municipal issues based on the strategy established by the municipal communication management will allow us to confirm the suitability of the messages of the members of the government team, the absence of contradiction between them, and to evaluate the reaction of the rest of the local political forces and the citizen-prosumers with respect to the municipal agenda. Therefore, the communicative structures must integrate new strategic models of integrated management, purpose-created software applications that enable the evaluation of the treatment of municipal information in online and conventional media, and the implementation of tools for monitoring social media and social networks.

For councils, knowledge management has become a valuable intangible asset that allows them to secure, refor- mulate, or question the strategy of the local government team during each legislative period. This fact justifies the integration in the municipal communication management office of new professional digital profiles such as the social media strategist, content manager, content curator, record manager and the community manager, which are going to strengthen relations with the conventional media, institutional communication, institutional relations management and the documentation, systematization and retrieval of public information.

\section{Notes}

1. Online reputation is associated with the prestige reached by a person, brand, or entity in the Internet environment. It depends on the opinions and conversations of users and citizens about our actions, events, or comments in the virtual context.

2. The Spanish Interactive Advertising Bureau (IAB, 2012) has offered the following classification of social media: blogs, photoblogs, microblogs, social networking sites, graphic utilities, professional networking sites, virtual worlds, dating sites, content aggregators, and in general any platform that offers users the possibility of generating shareable content.

\section{References}

Aerco-Territorio Creativo (2009). La función del community manager.

https://app.box.com/s/4v48/zewmz9uwujblya5

Aerco-PSM (2012). Community manager. Gestión de comunidades virtuales.

http://www.aercomunidad.org/wp-content/uploads/2015/07/ AERCO-PSM-Gesti\%C3\%B3n-de-comunidades-virtuales.pdf

Almansa-Martínez, Ana (2011). Del gabinete de prensa al gabinete de comunicación. Madrid: Comunicación Social. ISBN: 9788492860906

Álvarez-Domínguez, Tomás; Caballero Hueso, Mercedes (1999). Vendedores de imagen. Los retos de los nuevos gabinetes de comunicación. Barcelona: Paidós (Colección papeles de comunicación). ISBN: 8449303702

Ballester-Espinosa, Adrián (2013). “Análisis de la política de comunicación en Twitter de las Administraciones Públicas en la Comunidad Valenciana”. En: Gestión de la escasez, participación, territorios y estado del bienestar, pp. 209-219. Gogep Complutense.

https://goo.gl/uv5cxz

Bustelo-Ruesta, Carlota (2011). "Los grandes temas relacionados con la gestión de documentos: desafíos y oportunidades". El profesional de la información, marzo-abril, v. 20, n. 2, pp.129-133

https://doi.org/10.3145/epi.2011.mar.01

Campillo-Alhama, Concepción (2010). “Comunicación pública y administración municipal. Una propuesta de modelo estructural". Pensar la publicidad, v. IV, n. 1, pp. 45-62.

https://revistas.ucm.es/index.php/PEPU/article/view/ PEPU1010120045A 
Campillo-Alhama, Concepción (2011). Comunicación pública y gestión estratégica municipal. Un estudio exploratorio sobre la agenda temática. Colección Premios Blas Infante 2010. Sevilla: Instituto Andaluz de Hacienda y Administración Pública. ISBN: 9788483335598

Campillo-Alhama, Concepción (2013). "Gestión de la información y su evaluación en los gabinetes de comunicación municipal". El profesional de la información, v. 22, n. 6, pp. 515-521.

https://doi.org/10.3145/epi.2013.nov.03

Campillo-Alhama, Concepción; Ramos-Soler, Irene (2013).

"La comunicación 2.0 de las políticas orientadas a mayores en los ayuntamientos españoles". Estudios sobre el mensaje periodístico, v. 19, n. especial_abril, pp. 661-670.

https://doi.org/10.5209/rev_ESMP.2013.v19.42149

Carrillo-Durán, María-Victoria (2016). “Importancia del profesional de la información en la dirección de comunicación de las organizaciones". El profesional de la información, v. 25 , n. 2, pp. 272-278.

https://doi.org/10.3145/epi.2016.mar.14

Criado-Grande, Juan-Ignacio; Rojas-Martín, Francisco (2013). “Aproximación general sobre la adopción y uso de las redes sociales en las administraciones públicas". En: CriadoGrande, Juan-Ignacio; Rojas-Martín, Francisco. Las redes sociales digitales en la gestión y las políticas públicas. Avances y desafíos para un gobierno abierto, pp. 17-31. Generalitat de Catalunya: Escola d'Administració Pública de Catalunya.

https://dialnet.unirioja.es/servlet/libro?codigo=563897\&or den=1\&info=open_link_libro

Diputación de Alicante (2015). El community manager en la Diputación de Alicante

https://www.maytevs.com/wp-content/uploads/2015/03/Elcommunity-manager-en-la-diputaci\%C3\%B3n-de-Alicante.pdf

Díez-Lobo, Jesús (2004). "La información de las entidades locales". En: Bel-Mallén, José-Ignacio (coord.). Comunicar para crear valor. La dirección de comunicación en las organizaciones, pp. 259-271. Navarra: Eunsa. ISBN: 978 8431322489

Freixa-Matallonga, Ramón (2004). “El director de comunicación”. En: Bel-Mallén, José-Ignacio (coord.). Comunicar para crear valor. La dirección de comunicación en las organizaciones, pp. 125-138. Navarra: Eunsa. ISBN: 9788431322489

Gómez-Roa, Juan-Manuel (2013). “Las redes sociales, una potente herramienta al servicio del Open Government". En: Criado-Grande, Juan-Ignacio; Rojas-Martín, Francisco. Las redes sociales digitales en la gestión y las políticas públicas. Avances y desafíos para un gobierno abierto, pp. 119-139. Generalitat de Catalunya: Escola d'Administració Pública de Catalunya. ISBN: 9788469593974

http://americo.usal.es/iberoame/sites/default/files/criado_ redes_sociales_digitales.pdf

Graells-Costa, Jordi (2012). Redes sociales para transformar la administración pública (presentación). Madrid: Secretaría de Estado de Comunicación, Gabinete de la Presidencia del Gobierno. https://es.slideshare.net/jordigraells/redes-sociales-paratransformar-la-administracin-pblica

Guallar, Javier; Leiva-Aguilera, Javier (2013). El content curator. Barcelona: Editorial UOC, colección El profesional de la información, n. 24. ISBN: 9788490640180

Interactive Advertising Bureau, IAB Spain (2012). "Las 4 Rs de los medios sociales".

http://www.iabspain.net/wp-content/uploads/downloads/2012/06/ Las4R_MMSS_IAB_junio2012.pdf

Jiménez-Asensio, Rafael (2014). Vademécum de política municipal. Cómo gobernar un ayuntamiento. Euskadi: Instituto Vasco de Administración Pública. ISBN: 9788477774549

Moreno-Molina, Manuel (2014). El gran libro del community manager. Técnicas y herramientas para sacarle partido a las redes sociales y triunfar en los social media. Barcelona: Gestión 2000. ISBN: 9788498753417

Olías-de-Lima, Blanca (2001). La nueva gestión pública. Madrid: Pearson Educación. ISBN: 9788420531052

Palomar-Baget, Jesús (2013). "El uso de las redes sociales como herramientas formativas y comunicativas en la administración pública: estudio de caso de la EAPC". En: CriadoGrande, Juan-Ignacio; Rojas-Martín, Francisco. Las redes sociales digitales en la gestión y las políticas públicas. Avances y desafíos para un gobierno abierto, pp. 141-157. Generalitat de Catalunya: Escola d'Administració Pública de Catalunya. ISBN: 9788469593974

http://americo.usal.es/iberoame/sites/default/files/criado_ redes_sociales_digitales.pdf

Pérez-González, Rafael-Alberto (1988). Un modelo estratégico de comunicación municipal. Colección tesis doctorales, n. 242/88. Madrid: Universidad Complutense de Madrid.

Puig-Picart, Toni (2003). La comunicación municipal cómplice con los ciudadanos. Somos una marca de servicios pública con propuestas innovadoras y un estilo entusiasta. Barcelona: Paidós Comunicación. ISBN: 9788449314490

Ramió-Matas, Carles (1999). Teoría de la organización y administración pública. Barcelona: Tecnos/Universitat Pompeu Fabra. ISBN: 9788430934508

Ramírez-de-la-Piscina, Txema (1995). Gabinetes de comunicación: funciones, disfunciones e incidencia. Barcelona: Bosch. ISBN: 8476763115

Rojas-Martín, Francisco (2013). "Hacia las administraciones públicas 2.0.: Una propuesta de modelo teórico para el estudio de las redes sociales digitales". En: Criado-Grande, JuanIgnacio; Rojas-Martín, Francisco. Las redes sociales digitales en la gestión y las políticas públicas. Avances y desafíos para un gobierno abierto, pp. 33-43. Generalitat de Catalunya: Escola d'Administració Pública de Catalunya. ISBN: 97884 69593974

http://americo.usal.es/iberoame/sites/default/files/criado_ redes_sociales_digitales.pdf

Rubio-Oderiz, Loreto (2005). Singularidades de la gestión de la comunicación externa en las organizaciones públicas. 
Tesis doctoral. Barcelona: Universitat Ramon Llull.

Salaverría, Ramón (2016). "Redefinir al comunicador". El profesional de la información, v. 25, n. 2, pp. 163-167. https://doi.org/10.3145/epi.2016.mar.02

Timoteo-Álvarez, Jesús (2013). El manejo de la comunicación organizacional. Madrid: Díaz de Santos. ISBN: 97884 99694474

Vañó-Sempere, Mayte (2015). “Estrategias de implantación y gestión de las redes sociales en el sector público". En: Criado-
Grande, Juan-Ignacio; Rojas-Martín, Francisco. Casos de éxito en redes sociales digitales de las administraciones públicas, pp. 97-113. Generalitat de Catalunya: Escola d’Administració Pública de Catalunya. ISBN: 9788460655572

http://eapc.gencat.cat/web/.content/home/publicacions/col_ leccio_obres_digitals/20_casos_exito_redes_sociales/Casosde-exito-en-RSD-de-las-AA-PP.pdf

Villar-Rodríguez, Jorge (2016). Gestión y planificación de redes sociales profesionales. Bilbao: Deusto. ISBN: 97884 23425655

\section{Colección de libros de bolsillo \\ El profesional de la información (Editorial UOC)}

\section{Últimos títulos publicados}
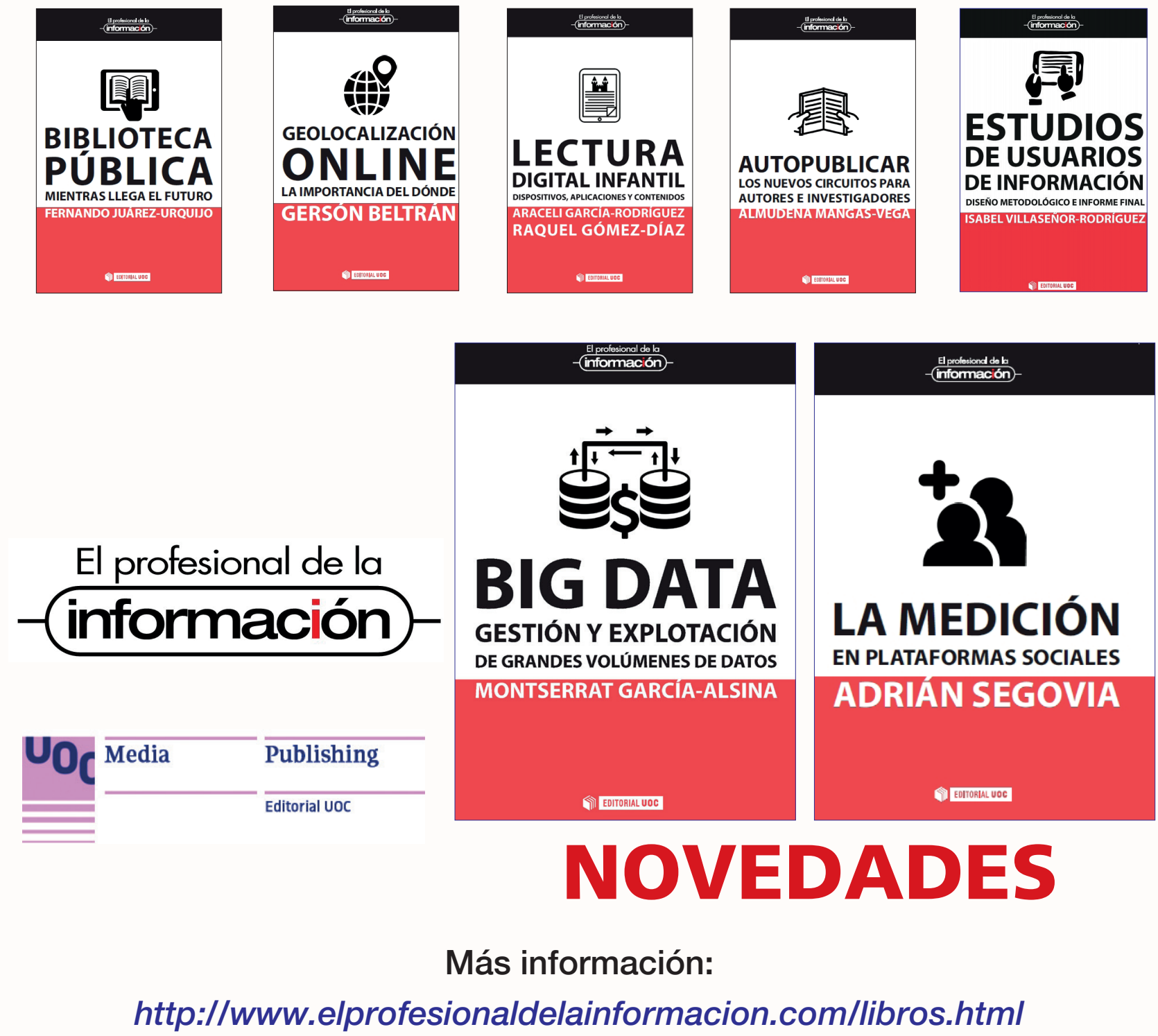